https://doi.org/10.18485/iipe_regbezb.2021.ch7

\title{
GERILSKE GRUPE KAO TRAJNA BEZBEDNOSNA PRETNJA ZA LATINOAMERIČKE ZEMLJE
}

\begin{abstract}
Rajko PETROVIĆ 1
Apstrakt: Predmet našeg istraživanja jeste delovanje gerilskih grupa na prostoru Latinske Amerike i bezbednosni izazovi koje ono sa sobom nosi. Polazimo od pretpostavke da su već 70 godina različite nacionalne i mahom levičarske paravojne gerilske grupe najveća bezbednosna pretnja, kako za tamošnje države pojedinačno tako i za latinoamerički region $\mathrm{u}$ celini. Rezultati istraživanja ukazuju na to da su neke gerilske grupe posle godina, pa čak i decenija, borbe odbacile oružanu borbu kao metod osvajanja vlasti i transformisale se u legalizovane političke pokrete ili partije, ali i da neke od njih i dalje deluju i ugrožavaju najpre bezbednost pojedinih država i celog regiona, a potom i političku stabilnost i ekonomski razvoj u njima. Zaključak je da su socijalna nejednakost, visoka stopa siromaštva, endemska korupcija i nedostatak razvijene demokratske kulture preduslovi koji pogoduju opstanku gerilske borbe zarad ostvarivanja političkih ciljeva u Latinskoj Americi, ali i garanti da će ovaj bezbednosni izazov i dalje biti prisutan na njenoj teritoriji. $U$ teorijskopojmovnom smislu objasnićemo pojam i značaj gerile, latinoameričkog modela diktature (kaudiljizam) i latinoameričke levice. U metodološkom smislu koristićemo se metodom studije slučaja, komparativnom metodom i metodom analize.

Ključne reči: Latinska Amerika, gerila, Montoneros, Revolucionarne oružane snage Kolumbije, Vojska za nacionalno oslobođenje, latinoamerička levica, kaudiljizam.
\end{abstract}

\footnotetext{
${ }^{1}$ Istraživač saradnik, Institut za evropske studije, Beograd.

E-mail: rajko.petrovic@ies.rs
} 


\section{UVOD}

Nakon završetka Drugog svetskog rata Latinska Amerika postaje politički i ekonomski nestabilno područje u kome se za vlast bore levičarske i desničarske političke partije i pokreti, ali i vojni krugovi (najčešće privrženi političkoj desnici) i paravojne levičarske organizacije inspirisane marksističkim revolucionarnim učenjem. Državni udari, vojni pučevi i stvaranje diktatorskih režima postali su realnost za većinu tamošnjih zemalja. Stoga nastaju gerilske grupe kao reakcija na desničarske diktature podržane vojskom poput diktature Augusta Pinočea (Augusto Pinochet) u Čileu, Horhea Rafaela Videle (Jorge Rafael Videla) u Argentini, Alfreda Stresnera (Alfredo Stroessner) u Paragvaju ili Anastasija Somoze (Anastasio Somoza) u Nikaragvi.

Decenijama unazad latinoameričke gerilske grupe bile su među najpoznatijima na svetu - Montoneros u Argentini, Tupak Katari (Túpac Katari) u Boliviji, Revolucionarne oružane snage Kolumbije (FARK), Patriotski front Manuel Rodrigez (Manuel Rodríguez) u Čileu, Front za nacionalno oslobođenje Farabundo Marti (Farabundo Martî) u El Salvadoru, Sandinistički front za nacionalno oslobođenje u Nikaragvi, Tupamaros $\mathrm{u}$ Urugvaju i drugi. Gerilski način ratovanja mnogima od njih donosio je velike uspehe, čemu je pogodovao niz uslova poput konfiguracije terena, zbijenih sirotinjskih gradskih četvrti, povodljivosti siromašnog i neobrazovanog stanovništva i sl. Vremenom su neke gerilske grupe odustale od ideje osvajanja vlasti nasilnim putem i kroz pregovore sa vlastima u datim zemljama uspele da se transformišu u zakonom priznate političke partije ili pokrete. To se desilo sa FARK-om u Kolumbiji, Farabundo Marti frontom u El Salvadoru, Manuel Rodrigez frontom $\mathrm{u}$ Čileu, sandinistima u Nikaragvi i Tupamarosima u Urugvaju. Sa druge strane, neke od latinoameričkih gerilskih grupa ne samo da su opstale, već i dalje sprovode nasilne akcije i na taj način ugrožavaju kako bezbednosnu tako i političku i ekonomsku stabilnost u pojedinim zemljama ili čak regionu u celini. Takav je slučaj sa gerilcima poput Vojske paragvajskog naroda (EPP) u Paragvaju, Zapatista u Meksiku, Vojske za nacionalno oslobođenje (ELN) u Kolumbiji i Sendero Luminoso u Peruu.

Nedovoljno razvijena demokratska politička kultura, izraženo raslojavanje između ekstremno bogatih i ekstremno siromašnih, tradicionalna sklonost latinoameričkih naroda ka militarizmu i skretanju u diktaturu, permanentno prisustvo Sjedinjenih Američkih Država u regionu 
shvaćenom kao „njihovo dvorište“, klanovski kriminal i korupcija najgore vrste, te sklonost ka zavodljivosti širokih masa populizmom ključni su faktori koji pogoduju nastanku, razvoju i većem ili manjem uspehu gerilskih grupa na tim prostorima. Stoga one predstavljaju permanentan bezbednosni izazov za gotovo sve zemlje Latinske Amerike.

Nema sumnje da je najuspešnija i najčuvenija latinoamerička gerilska grupa bio Pokret 26. jul (M-26-7), predvođen Fidelom Kastrom (Fidel Castro), koji je tokom Kubanske revolucije zbacio sa vlasti diktatora Fulhensija Batistu (Fulgencio Batista) i uspostavio komunistički režim koji i danas traje. Ona je ostavila ogroman uticaj na gerilske grupe širom regiona i dala im nadu da se oružanom borbom mogu ostvariti željeni ciljevi. Ipak, smatramo da je reč o pokretu i događaju koji zavređuju posebnu i detaljniju pažnju, a za koju u ovako koncipiranom istraživanju nije bilo mesta.

\section{TEORIJSKO-POJMOVNI OKVIR}

Gerilsko ratovanje predstavlja specifičan oblik oružane borbe koji je primenjivan vekovima, ali se o njemu u teorijskom smislu govori tek s kraja XVIII i početkom XIX veka. Pisani tragovi govore da su gerilski način ratovanja primenjivali drevni Sumeri, zatim Egipćani protiv Hiksa, robovi u staroj Grčkoj i Rimu, kao i Sloveni protiv Vizantije. Sam termin i teorijski koncept gerile dolazi iz vremena Napoleonovih ratova u Evropi, a posebno $\mathrm{u}$ vreme francuskog osvajanja Španije. Tada je otpor španskog naroda zavojevaču nazvan guerrilla, što na španskom jeziku znači mali rat (Milašinović and Putnik 2007, 327). Gerila se definiše kao „,oblik oružanog otpora stanovništva ili njegovog dela, grupa u jednoj zemlji ili području u uslovima u kojima nije moguće vođenje adekvatne borbe protiv jačeg, materijalno i silom nadmoćnijeg protivnika koji je ili osvajač ili vladajuća struktura sopstvene zemlje“ (Milašinović and Putnik 2007, 328). Shvaćena kao borba za samoopredeljenje, pokret otpora ili partizansko ratovanje, gerila je priznata u okviru međunarodnog ratnog prava. Prema Dopunskom Protokolu I iz 1977. godine status boraca koji bi se mogli označiti terminom gerilci je ozakonjen, odnosno stavljen pod ingerencije međunarodnog ratnog prava (Milašinović and Putnik 2007, 329-330). Gerila se često meša sa terorizmom, što je pogrešno. Iako i gerila i terorizam spadaju oblike političkog nasilja, među njima postoji bitna razlika. Naime, gerila po definiciji predstavlja zakonitu borbu protiv okupatora, a gerilci 
načelno borce za slobodu koji streme građanskim slobodama kao cilju borbe. Sa druge strane, teroristi se $u$ ostvarivanju svojih ciljeva služe nasiljem i strahom, a meta su im neretko i civili. $U$ tom smislu, terorizam najčešće ima negativnu konotaciju, a gerila pozitivnu ili bar neutralnu, iako i sami gerilci neretko primenjuju istu taktiku borbe kao i teroristi, poput atentata, otmica i podmetanja bombi na javnim mestima (Krstić 2015, 520521). Gerilske grupe su tokom XX veka bile prisutne na praktično svim delovima planete - od Crnačke oslobodilačke vojske (Black Liberation Army) u Sjedinjenim Američkim Državama, preko tzv. Oslobodilačke vojske Kosova u Evropi, preko Somalijskog nacionalnog pokreta (Somali National Movement) $\mathrm{u}$ Africi i Tamilskih tigrova (Liberation Tigers of Tamil Eelam) $\mathrm{u}$ Aziji, sve do Revolucionarne vojske Bugejnvila (Bougainville Revolutionary Army) u Okeaniji. Ako zanemarimo mnoštvo gerilskih pokreta na afričkom kontinentu, koji su bili prirodan deo procesa dekolonizacije tog prostora $u$ XX veku, videćemo da je Latinska Amerika prostor na kome se, zapravo, $u$ okviru postojećih međunarodno priznatih zemalja (koje su se oslobodile evropskih kolonijalnih sila još u XIX veku) javio najveći broj gerilskih grupa, od kojih su mnoge i danas aktivne.

Latinska Amerika je prostor na kome su države u XIX veku stekle samostalnost od nekadašnjih evropskih kolonijalnih sila, pre svih Španije i Portugala. Iako je lokalno stanovništvo predvođeno kreolima krenulo u proces izgradnje država po francuskom i američkom demokratskom receptu, specifična autoritarna politička kultura nastala $u$ vreme kolonijalizma ostala je još dugo dominantna matrica društveno-političkih odnosa. Nekadašnji kacikizam (caciquismo), koji je označavao sistem u kome lokalni vlastodržac (cacique) ima punu kontrolu nad političkim, ekonomskim i društvenim tokovima, u XIX i XX veku je zamenjen kaudiljizmom (caudillismo). Reč je o političkom fenomenu specifičnom za latinoameričko podneblje $\mathrm{u}$ kome je vlast koncentrisana $\mathrm{u}$ rukama harizmatičnog vođe (caudillo) dopadljivog širokim masama, populističke retorike i delovanja, sklonog represivnim merama protiv neistomišljenika i političkih protivnika, te neretko i zavođenju diktature (Castro 2007, 10). Kaudiljizam je u savremenoj Latinskoj Americi najčešće imao desničarsko, militantno i ksenofobično ruho. Nesporno je da je i latinoamerička levica iznedrila lidere koji se uklapaju u matricu kaudiljizma, poput Uga Čaveza (Hugo Chávez) ili Eva Moralesa (Evo Morales), ali ih je daleko više bilo na desnom političkom spektru, verovatno procentualno najviše u odnosu na ostatak sveta. Augusto Pinoče, Horhe Rafael Videla, Alfredo Stresner, 
Anastasio Somoza i Rafael Truhiljo (Rafael Trujillo) najpoznatiji su protagonisti latinoameričkog kaudiljizma i neki od najpoznatijih diktatora u XX veku uopšte. Desničarski režimi koji su krajem XIX i tokom celog XX veka nicali jedan za drugim na ovom prostoru imali su manje-više identične karakteristike - apsolutna vlast koncentrisana u pojedincu, gušenje slobode političke misli i delovanja, kontrola ekonomskih tokova u zemlji, snažna sprega vlasti i vojske, fasadna demokratija oličena u postojanju institucija provizornog karaktera i brisanje granica između javne i privatne sfere (Castro 2007, 15-20). Posebno je zanimljiv njihov izrazito negativan i agresivan odnos prema marksističkim levičarskim ideologijama na njihovom tlu sa kojima su se nemilosrdno obračunavali. Dovoljno je uzeti primer Čilea, gde je za vreme militarističke diktature Augusta Pinočea ubijeno oko 3.000, mučeno 30.000 i uhapšeno 130.000 Čileanaca koje je je režim dovodio u vezu sa "antidržavnim" levičarskim organizacijama (Петровић 2020, 17).

Levičarske ideologije oduvek su imale plodno tle u Latinskoj Americi, što nije čudno, s obzirom na izraženo socijalno raslojavanje stanovništva, stepen ekonomske nejednakosti između bogatih i siromašnih, mešanje Sjedinjenih Američkih Država u unutrašnja pitanja datih država (latinoamerička levica je po pravilu nacionalistička) i sl. Desničarske diktature su, međutim, bile idealno „pogonsko gorivo“ za razvoj i širenje marksističkih ideja prilagođenih potrebama latinoameričkog podneblja. Represivna i militaristička desnica na vlasti je po prirodi stvari rađala levicu sklonu različitim oblicima političkog nasilja, među koje spada i gerila. Tako su mnogi levičarski pokreti u Latinskoj Americi na vlast dolazili revolucijama, poput Kubanske (1959) i Sandinističke (1979). Gotovo svi militantni levičarski pokreti na ovom prostoru služili su se gerilom. Bez obzira na to da li su bili motivisani lošim socio-ekonomskim stanjem u zemlji, nedostatkom političkih prava i sloboda, ili pak željom za emancipacijom i poboljšanjem sveukupnog položaja urođeničkih naroda, svim tim pokretima se gerilska borba činila kao idealno sredstvo za ostvarivanje ciljeva. Mirno osvajanje vlasti na demokratskim izborima u nekim slučajevima bilo je skoro pa nemoguće, dok je u drugim bilo moguće tek nakon što su gerilci svojom borbom stvorili uslove za iste. Usled nedostatka materijalnih i ljudskih resursa, te u skladu sa konfiguracijom terena (prašume, nepristupačne planine i sl.) i gustinom naseljenosti (stanovništvo koncentrisano mahom u priobalnim gradovima, koji su bili 
striktno podeljeni na bogate i siromašne četvrti), strategija gerilskog ratovanja se nametala kao efikasna i svrsishodna.

\section{GERILSKE GRUPE U LATINSKOJ AMERICI: NASTANAK I OSNOVNE KARAKTERISTIKE}

Političko nasilje je, u svojim različitim oblicima, vekovima bilo prisutno na prostoru Latinske Amerike. Uz pomoć njega Španci, Portugalci i drugi evropski kolonizatori uspešno su kontrolisali taj prostor preko 300 godina. Revolucije za nacionalno oslobođenje latinoameričkih zemalja same po sebi su proizvele ogromnu količinu političkog nasilja. Sa proterivanjem kolonizatora nasilna komponenta političkog života nije nestala, naprotiv, veliki broj novostvorenih zemalja je prošao kroz tragična iskustva građanskih ratova ili međusobnih sukoba. Čak su i latinoameričke zemlje koje važe za "najevropskije“, poput Argentine i Čilea, odmah po sticanju nezavisnosti utonule $\mathrm{u}$ građanske ratove, a potom i ratove sa susedima. Neokolonijalna matrica odnosa moći zadržala se i posle odlaska Španaca i Portugalaca, ispoljavajući se kroz nasilne političke obračune, zavođenje diktatura, upotrebu vojske $\mathrm{u}$ političke svrhe, te kroz stvaranje uske političke, vojne i ekonomske elite koja je kontrolisala sve tokove u datim zemljama. U tom kontekstu treba razumeti i nastanak i razvoj gerilskih grupa širom Latinske Amerike.

Uopšteno govoreći, gerilske grupe postaju široko rasprostranjen fenomen na tom prostoru od 1950-ih i na desetine ih nastaje do 1980-ih. Teško je precizirati kada se tačno javlja prva gerilska grupa na tom prostoru. Ukoliko $\mathrm{u}$ obzir uzmemo one čije delovanje je izazvalo ne samo interesovanje šire javnosti, već i proizvelo dugoročne posledice, onda se može reći da je prva nastala u Nikaragvi, predvođena Augustom Sandinom² (Augusto Sandino) 1920-ih, a nedugo za njom i u El Salvadoru,

\footnotetext{
${ }^{2}$ Upravo je po Augustu Sandinu ime poneo Sandinistički front nacionalnog oslobođenja (FSLN), nikaragvanska marksistička gerilska grupa osnovana 1961. godine s ciljem borbe protiv diktatorskog režima Anastasija Somoze. Sandinisti su najpre tokom 1970-ih izveli niz gerilskih napada, da bi 1979. godine pokrenuli sveopštu revoluciju u kojoj su srušili tadašnji režim. Nakon toga su se transformisali u političku partiju sa istim nazivom, koja je vladala sve do 1990. godine. Na vlast se ponovo vraća 2006. godine predvođena Danijelom Ortegom (Daniel Ortega), gde je ostala sve do danas (Salgado 2018).
} 
predvođena Farabundom Martijem. Prvi nikaragvanski gerilci, na čelu sa čovekom po čijem će prezimenu kasnije naziv poneti jedna od najuticajnijih gerilskih grupa u Latinskoj Americi, a potom i revolucija i najsnažnija nikaragvanska politička partija, bili su zapravo paradigmatičan primer latinoameričke levičarske gerile. Sandino je bio predvodnik radničkog i siromašnog sloja Nikaragve u pobuni protiv režima Anastasija Somoze i otporu protiv okupacije te zemlje od strane Sjedinjenih Američkih Država (1927-1933). Prvi nikaragvanski gerilci su se, dakle, borili protiv represije desničarske diktature, surovog ekonomskog liberalizma u kome je malobrojna elita bila povlašćena, odnosno za poboljšanje socijalnog statusa najranjivijih društvenih grupa, ali i protiv narušavanja suvereniteta Nikaragve od strane zvaničnog Vašingtona, koristeći zasede kao najefikasniji metod borbe (Grossman 2008). Ovo je kasnije manje-više postala "lična karta“" svih latinoameričkih levičarskih gerilaca, uz obavezan kult vođe revolucije koji je svoj život položio za slobodu naroda i otadžbine, kao što se desilo sa Sandinom koji je ubijen po Somozinom naređenju 1934. godine. Isti obrazac se ponovio i u slučaju El Salvadora. Tamo je marksistički revolucionar Farabundo $\mathrm{Marti}^{3}$ organizovao lokalne radnike i seljake u gerilske grupe kako bi pružili otpor diktatorskom režimu Maksimilijana Ernandeza Martineza (Maximiliano Hernández Martínez) tokom Masakra seljaka 1932. godine, kada je državna armija izvršila etnocid nad urođeničkim Pipli narodom. Baš kao u Nikaragvi, i ovde su se gerilci borili protiv domaće diktature podržane spoljnom američkom intervencijom, i bili organizovani hijerarhijski i podeljeni u veći broj manjih grupa koje su vršile zasede i napadale strateške tačke vojno nadmoćnijeg protivnika (Arias Gómez 2012).

S obzirom na to da ćemo na narednim stranama analizirati pojedinačne gerilske grupe, ovde ćemo ukazati na njihove zajedničke karakteristike. Prvo, rane latinoameričke gerilce ne treba posmatrati kao teroriste ili političke ekstremiste, jer oni nisu imali druge mogućnosti u situaciji u kojoj su diktatorski režimi blokirali svaku mogućnost za mirne i demokratske

\footnotetext{
${ }^{3}$ Po Farabundo Martiju je ime dobio Farabundo Marti front za nacionalno oslobođenje (FMLN), salvadorska marksistička gerilska grupa formirana 1980. godine ujedinjenjem nekolko manjih levičarskih grupa. Bila je jedan od glavnih učesnika u Salvadorskom građanskom ratu (1979-1992), koji je završen primirjem između desničarske vlade i levičarskih pobunjenika. FMLN je transformisan u političku partiju i vršio je vlast u periodu između 2009. i 2019. godine (Álvarez 2011).
} 
promene (Larson 1977, 112). Drugo, latinoameričke gerilske grupe su po mnogo čemu sličnije afričkim ili azijskim, negoli evropskim - zbog neokolonijalnog konteksta, stranog intervencionizma i socio-ekonomskih okolnosti (Larson 1977, 112). Treće, one imaju nacionalistički, antiglobalistički i antineoliberalni karakter (Joxe 1997). Četvrto, savremene gerilske grupe su daleko bolje naoružane i imaju razvijeniju logistiku i infrastrukturu nego što je to bio slučaj sa starim. Isto tako, imaju daleko više slobode i autonomije, jer $\mathrm{u}$ ideološkom i politčkom smislu nisu vezane za spoljne faktore, kao što je to bio slučaj ranije zbog pomoći od strane komunističkih režima širom sveta (Joxe 1997). Peto, ruralno stanovništvo je mahom predstavljalo okosnicu svih gerilskih grupa u Latinskoj Americi, jer upravo ono neguje tradiciju različitih vidova pobune protiv vlasti (Hobsbawm 1970, 51). Šesto, istorijski posmatrano, latinoameričke gerilske grupe su imale i imaju značajan revolucionarni potencijal (Hobsbawm 1970, 53).

\section{STUDIJE SLUČAJA}

\section{Montoneros}

Studije slučaja, koje će nam pomoći da razumemo značaj gerilskih grupa i njihovu opasnost (kako nekada tako i sada) po bezbednost latinoameričkih zemalja i Latinske Amerike kao svetskog regiona uopšte, započećemo sa argentinskim gerilcima zvanim Montonerosi. Nakon što je vojnim udarom 1955. godine, predvođenim Eduardom Lonardijem (Eduardo Lonardi), prekinut drugi mandat vlade Huana Perona (Juan Perón), a sam Peron proteran u Španiju, Argentina je ušla u gotovo dvodecenijski period unutrašnjih sukoba između peronista i antiperonista, gde dolazi do čestih smena između civilne i vojne vlasti. U takvoj atmosferi krajem 1960ih godina nastaje ova levičarska peronistička gerilska grupa. Iako veza između samog Perona u egzilu i ove grupe nikada do kraja nije rasvetljena, Montoneros se zalagao za njegov povratak i za povratak tekovina „Peronove revolucije“ u javnu sferu (Amorin 2005). Ovi gerilci su od samog početka svog višegodišnjeg delovanja (1970-1981) primenjivali nasilne metode borbe, smatrajući da će na takav način izazvati revolt vlasti i ogoliti njen diktatorski karakter. Iako nikada nije uspeo da mobliše široke narodne mase, Monteneros je svojim aktivnostima uneo veliku pometnju u ionako nestabilno argentinsko društvo. Pažnju javnosti dobili su već 1970 . godine 
kada su oteli i ubili bivšeg argentinskog diktatora Pedra Euhenija Aramburua (Pedro Eugenio Aramburu) i njegove saradnike, a koje su teretili za masakr nad neistomišljenicima i ubistvo argentinskog generala Huana Hosea Valjea (Juan José Valle) 1956. godine. Dve godine kasnije postavili su eksploziv na Trg Svetog Isidra u Buenos Ajresu (i tom prilikom ubili jednu, a ranili nekoliko osoba), a potom izazvali eksploziju u jednom od prestižnih hotela u prestonici. Godine 1973. ponovo su uzburkali argentinsku javnost ubistvom pukovnika Hektora Irabarena (Héctor Irabarren), jednog od čelnih ljudi argentinske obaveštajne službe (Lewis 2002).

Peronisti su 1973. godine osvojili vlast na prvim demokratskim izborima posle dužeg vremena pauze, kada se i sam Peron vraća iz Španije. Iako su Montonerosi za to imali značajne zasluge, Peron se najpre distancirao od njih, a potom ih i izbacio iz svoje Justicijalističke partije 1974. godine. Izabela Peron (Isabel Perón), Peronova supruga i predsednica Argentine od 1974. do 1976. godine dekretom je proglasila Montonerose subverzivnom grupom i naredila njihovo uklanjanje. Montoneros je $\mathrm{u}$ međuvremenu nastavio sa gerilskom borbom. Godine 1974. ubili su šefa peronista u gradu Rosariju Teodora Ponsea (Teodoro Ponce), a zatim i bivšeg argentinskog ministra spoljnih poslova Artura Mora Rođa (Arturo Mor Roig). Nastavili su sa sabotažama u fabrikama, sredstvima javnog prevoza, ali i sa otmicama protivnika i predstavnika biznis klase (Jenkins and Johnson 1976, 2). Pored ubistava istaknutih pojedinaca, Montoneros je 1975. godine izveo i veliku vojnu operaciju "Primisija“", kada su oteli jedan avion i napali vojne barake $\mathrm{u}$ argentinskoj provinciji Formosa, ubivši i ranivši desetine vojnika i civila. Pored vojnih objekata i pripadnika oružanih snaga, napada nisu bili pošteđeni ni novinari i njihove redakcije. Međutim, već 1976. godine na vlast dolazi vojna hunta predvođena generalom Horhe Rafaelom Videlom. Videla se na vlasti zadržao sve do 1981. godine, a protiv svojih političkih protivnika je vodio nemilosrdnu i nasilnu borbu tokom čuvenog Prljavog rata u kome je život izgubilo nekoliko desetina hiljada ljudi. Na najvećem udaru vojne hunte našao se upravo Montoneros, tada predvođen Mariom Firmeničem (Mario Firmenich). Usledili su višegodišnji ulični ratovi, otmice, bombaški napadi, zarobljavanja i mučenja u kojima je stradalo na hiljade civila, nekoliko hiljada gerilaca, ali i na desetine vojnika i policajaca, kao i ljudi iz samog vrha politike i vojske (Muñoz 2011).

Uprkos velikom otporu Montonerosa, Videla je uspeo da do 1981. godine u potpunosti neutrališe ovu grupu. Videla je ubrzo zbačen sa vlasti, a poraz od Britanaca u Folklandskom ratu 1982. godine označio je kraj militarističke 
ere i početak demokratske tranzicije Argentine $u$ kojoj više nije bilo prostora za ozbiljnije gerilsko delovanje. Možemo zaključiti da se Montoneros služio tipičnom taktikom za latinoameričke gerilce - otmice i ubistva visokih političkih i vojnih funkcionera (ali i novinara), bombaški napadi na javnim mestima, strateški napadi na vojne i policijske centrale, te uništavanje proizvodnih pogona i saobraćajne infrastrukture. Montoneros je paradigma snažne latinoameričke gerilske grupe koja, uprkos tome što je imala veliki broj pripadnika i sposobnost da ozbiljno ugrožava funkcionisanje poltičkog poretka u zemlji, nije uspela da opstane kako zbog rešenosti države da je neutrališe tako i zbog nadolazećeg procesa demokratizacije države i društva.

\section{FARK-EP}

Revolucionarne oružane snage Kolumbije - Vojska naroda (FARC-EP), u široj javnosti poznatije pod skraćenicom FARK, jedna su od najpoznatijih gerilskih grupa u istoriji Latinske Amerike. FARK je osnovan davne 1964. godine i delovao je sve do 2016. godine, kada je postignut dogovor o miru sa vladom Kolumbije, gde se FARK godinu dana kasnije transformisao u zakonom priznatu političku partiju pod nazivom Zajednička alternativna revolucionarna snaga (Fuerza Alternativa Revolucionaria del Común), čija je skraćenica ostao FARK. Ova grupa, dakle, spada u red onih latinoameričkih gerilskih grupa koje su svojim relativno uspešnim višedecenijskim vojnim delovanjem naterale vladu svoje zemlje da sa njima potpiše primirje i prizna ih kao relevantnu i zakonski priznatu političku snagu. Treba istaći da je FARK nastao na marksističko-lenjinističkim ideološkim osnovama, te s ciljem pretvaranja Kolumbije u socijalističku državu. Uzroci njegovog nastanka sežu u daleku 1948. godinu, kada su desničarske elite podržane narko-kartelima ubile lidera kolumbijskih socijalista Horhea Eliesera Gajetana (Jorge Eliécer Gaitán), čoveka veoma popularnog u narodu i viđenog kao budućeg predsednika Kolumbije. Usledilo je desetogodišnje nasilje i obračuni (La Violencia) između desničarske vlasti i levičarskih pokreta i partija u kojima je živote izgubilo preko 200.000 ljudi. FARK nastaje u uslovima kada vlada Kolumbije planira da zabrani rad ostalih političkih partija u zemlji. Radničko i seljačko stanovništvo je kao odgovor na ovakav potez vlade krenulo sa osnivanjem ",komunističkih republika“ širom zemlje, a nakon što je vojska krvavo ugušila jednu od njih u Maketaliji nastaje FARK predvođen Pedrom Antoniom Marinom (Pedro Antonio Marín) i počinje poluvekovni građanski rat (Offstein 2003, 101-105). 
FARK se decenijama služio klasičnim gerilskim metodama borbe protiv kolumbijske vlade - napadima na vojne i policijske trupe, atentatima, bombaškim napadima, kidnapovanjima, ali i preuzimanjem dela lanaca trgovine drogom. Vlada Kolumbije i međunarodne organizacije tokom višedecenijskog delovanja teretile su FARK i za čitav niz kršenja ljudskih prava, među kojima su i masakri čitavih sela, progon stanovništva na teritoriji pod njihovom kontrolom, mučenje i ubijanje zatvorenika i silovanje žena i devojčica. Treba istaći da je FARK bila veoma brojna gerilska grupa, koja je u nekim trenucima imala skoro 20.000 naoružanih i dobro obučenih boraca, a nikada ispod nekoliko hiljada. Zbog svega ovoga FARK je dugo vremena važio za najopasniju gerilsku grupu na zapadnoj hemisferi. Vladine vojne i policijske snage, potpomognute desničarskim paravojnim formacijama i narko-kartelima neretko su uzvraćale istom merom. Pored FARK-a, sa vladinim snagama su se sukobljavale i druge gerilske grupe (poput ELN-a), ali je on definitivno bio njen najmoćniji i najopasniji neprijatelj. Ukupan rezultat višedecenijskih sukoba jesu milioni raseljenih i izbeglih lica, 215.000 poginulih civila, 46.800 poginulih boraca na obe strane, 70.000 nestalih, 37.000 otetih i 15.000 silovanih žena (Romero 2018). Ovo su podaci koji svedoče o razornoj moći ove gerilske grupe, kao i o ogromnom uticaju koji je ostavila na celokupnu savremenu istoriju Kolumbije.

FARK je za pola veka svog delovanja izveo na stotine atentata, masakara, otmica i bombaških napada. Neki od njegovih najznačajnijih bombaških napada bili su napad na antigerilsko vojno postrojenje u El Doradu 2002. godine (29 poginulih), napad na klub „El Nogal” u Bogoti 2003. godine (36 poginulih i preko 200 ranjenih) i napad na palatu pravde u Kaliju 2008. godine (4 poginulih i 26 ranjenih). Od atentata se izdavaja pokušaj ubistva predsednika Kolumbije Alvara Uribea (Álvaro Uribe) u blizini aerodroma u Neivi 2003. godine, kada je poginulo 15 i ranjeno 66 ljudi. Samo tokom leta 2015. godine, tik uoči potpisivanja primirja sa vladom Kolumbije, FARK je izveo čak 64 napada (Defensoría del Pueblo 2015). Od preko 9.000 otmica, najpoznatija je bila otmica tadašnje kandidatkinje za mesto predsednika Kolumbije Ingrid Betankur (Íngrid Betancourt) 2002. godine, a koja je oslobođena tek 2008. godine (Betancourt 2010). Od preko 240 počinjenih masakara, najpoznatiji su oni u kanjonu reke Ata, Pavarando Grandeu, Behukalesu, Apartadu, Tieralti, Bohaji, Narinju i El Saladu (Nubia Bello 2013, 47-56).

Sve prethodno rečeno ukazuje na vojnu, organizacionu i logističku snagu FARK-a tokom njegove poluvekovne istorije. S obzirom na činjenicu da vlada Kolumbije nije uspevala da eliminiše ovu pretnju (koristila je razne 
načine, poput infiltriranja svojih ljudi među gerilce, lažnog primirja 1980ih, opsežnih vojnih i policijskih akcija), započela je konačne mirovne pregovore 2012. godine koji su rezultirali primirjem potpisanim 2016. godine. FARK je transformisan u političku partiju koja se obavezala da će se mirnim i demokratskim putem boriti za vlast, iako je ostalo par manjih grupa unutar kolumbijske teritorije koje su odbile poslušnost. Nova partija je pripremala Rodriga Londonja (Rodrigo Londoño) kao kandidata na predsedničkim izborima 2018. godine, ali se od kandidature odustalo zbog njegovih zdravstvenih problema. Političko „krštenje“ imala je na lokalnim izborima 2019. godine, gde je osvojila dva gradonačelnička mesta (Pupiales 2019). Još uvek, međutim, vlada nepoverenje između vlade i bivših gerilaca, iako je FARK gotovo u potpunosti razoružan i već godinama ne izvodi napade. U svakom slučaju, ovo je primer gerilske grupe koja je, poput pomenutih u Nikaragvi i El Salvadoru, imala dovoljno snage da se nametne kao relevantan politički faktor priznat od strane zvaničnih vlasti.

\section{ELN}

Vojska za nacionalno oslobođenje (Ejército de Liberación Nacional), poznatija pod skraćenicom ELN, jedna je od najmoćnijih i najdugotrajnijih aktivnih gerilskih grupa u Latinskoj Americi, te kao takva predstavlja idealan primer onih koje vlasti nisu uspele da poraze vojničkim putem, niti da sa njima uspostave trajno primirje. Ova kolumbijska gerilska grupa je formirana davne 1964. godine i zasnovana je na marksističko-lenjinističkoj i gevarističkoj ideologiji uz primese "teologije oslobođenja“. Cilj grupe od samog početka bilo je osvajanje vlasti oružanim putem i uspostavljanje komunističkog poretka u Kolumbiji. Shodno tome, grupa se našla na udaru kako kolumbijske vlasti, tako i paravojnih desničarskih formacija (Azzellini 2009, 1081-1084). Isto tako, proglašena je terorističkom organizacijom u Sjedinjenim Američkim Državama (protiv čijeg se navodnog imperijalizma u Kolumbiji bori), Kanadi, Evropskoj uniji i susednom Peruu. Sa druge strane, ELN je tokom decenija delovanja imao različite formalne i neformalne saveznike - FARK (do potpisivanja primirja 2016), zatim u prošlosti i Sovjetski Savez, Kinu i Kubu, a danas računa na podršku jedino Madurove (Nicolás Maduro) Venecuele ${ }^{4}$ (ICG 2019, 5). Zanimljivo je to da je

\footnotetext{
${ }^{4}$ Venecuelanska opozicija predvođena samoproglašenim predsednikom Venecuele Huanom Guaidom (Juan Guaidó) ELN smatra terorističkom organizacijom.
} 
ELN od samog početka privukao veliki broj sveštenika rimokatoličke crkve koji su se protivili ideologiji vladajuće elite, od kojih su neki postali jedni od čelnih ljudi grupe, poput Kamila Toresa Restrepa (Camilo Torres Restrepo) i Manuela Pereza Martineza (Manuel Pérez Martínez).

Sa svojih nekoliko hiljada dobro obučenih boraca, ELN je izveo na stotine bombaških napada, atentata i otmica širom zemlje. Na meti su mu bili političari, vojnici, policajci, novinari, ali i građani za koje se sumnjalo da sarađuju sa vlašću u borbi protiv njega. On je najpre surovo kažnjavao sve bivše članove grupe za koje se smatralo da su saradnici sa vlašću i izdajnici. Tako su 1968. godine zbog navodne izdaje ubijena tri uticajna člana ELN - Viktor Medina Moron (Victor Medina Morón), Hulio Sesar Kortes (Julio César Cortés) i Eliodoro Očoa (Heliodoro Ochoa). Tri godine kasnije ubijen je i Haime Arenas Rejes (Jaime Arenas Reyes), vođa kolumbijskih studenata, jer je napustio grupu i zalagao se za dijalog sa vlašću (Arenas Reyes 1971). Vidimo, dakle, da je ova gerilska grupa od samog početka insistirala na unutrašnjoj koheziji i nije dozvoljavala nikakva odstupanja od ideoloških postulata formulisanih još u Manifestu iz Simakote, gradu u provinciji Santander u kome je ELN izvršio svoj prvi oružani napad 1964. godine. Baš kao i FARK i ELN je bio sposoban da vojnički zauzme čitava sela ili manje gradove. Tako je, primera radi, 1970. godine zauzeo gradić Simitaru na severoistoku zemlje $\mathrm{u}$ provinciji Santander. Sa atentatima na visokopozicionirane Kolumbijce počeli su vrlo rano. Prvi koji je odjeknuo u javnosti bio je neuspeli atentat na Alvara Valensiju Tovara (Álvaro Valencia Tovar), jednog od vodećih kolumbijskih oficira, ispred zgrade ministarstva odbrane u Bogoti 1971. godine. Kolumbijska vlada je ELN shvatila kao ozbiljnu pretnju i 1972. godine je započela "Operaciju Anori“, prvu veliku operaciju protiv ove gerilske grupe u kojoj je uhapšeno preko 200 osoba koje su dovedene u vezu sa njom. ELN je od 1978. do 1998. godine vodio sveštenik Manuel Perez Martinez (Manuel Pérez Martínez), koji je uspeo da mudrim rukovođenjem pomiri zavađene frakcije unutar grupe, a serijom pljački nekoliko evropskih multinacionalnih kompanija finansijski osnaži i vojno modernizuje ELN. Tokom 1980-ih ELN se udružuje sa FARK-om i drugim levičarskim gerilskim grupama $\mathrm{u}$ Kolumbiji i učestvuje $\mathrm{u}$ nekoliko napada na kolumbijsku vojsku i njene objekte, od kojih se izdvaja napad na vojnu bazu u El Bagreu, gde je ubijeno 15 vojnika. Nakon neuspelih pregovora sa vladom Kolumbije početkom 1990-ih, ova decenija je bila obeležena nizom ofanzivnih napada ELN-a, među kojima su napadi u Usmeu, Mutati i 
Guikanu koji su odneli nekoliko desetina života. Uz to, ELN je sredinom 1990-ih započeo sa akcijama sabotaže rada vladinih naftnih postrojenja sa prilično velikim uspehom. Nakon neuspelih pregovora sa vladom predsednika Alvara Uribea (Álvaro Uribe) početkom 2000-ih grupa je nastavila sa napadima na vojsku, policiju i strateški važne objekte u zemlji, učvršćujući svoju saradnju sa manjim gerilskim grupama i narko-kartelima suprotstavljenim vlastima, ali se istovremeno obračunavala sa FARK-om zbog taktičkih i strateških mimoilaženja (Echandía Castilla 2013). Svi naredni mirovni pregovori između ELN-a i vlade Kolumbije, uključujući i one od 2015. do 2017. godine su propali, uprkos najvećim postignućima do tada (razmena zatvorenika, stvaranje uslova za dolazak pape Fransiska $u$ Kolumbiju 2017. i sl.). Za razliku od FARK-a, ELN nije pristao na poslednje uslove primirja koje je ponudila vlada u Bogoti i time je od 2016. godine postao najsnažnija gerilska grupa u zemlji.

ELN i danas izvodi napade $\mathrm{u}$ raznim delovima Kolumbije, posebno $\mathrm{u}$ severoistočnom na granici sa Venecuelom. Iako su najavljeni novi pregovori u 2021. godini, prethodna godina je bila obeležena sa nekoliko akcija ELN-a, gde su u poslednjoj ubijena dva mlada vojnika u gradiću Tibu u provinciji Severni Santander. Aktuelni predsednik Kolumbije Ivan Duke (Iván Duque) optužuje režim Nikolasa Madura u Karakasu da je odgovoran za nemogućnost postizanja trajnog mira sa ELN-om, jer ga materijalno pomaže i dozvoljava njegovim pripadnicima da nesmetano prelaze granicu između dve zemlje. Uz to, obuka, finansiranje i obaveštajna pomoć ELN-u pripisuje se i Komunističkoj partiji Kube (Demarest 2020, 86). Upravo zato su, između ostalog, Sjedinjene Američke Države nedavno stavile Kubu na spisak država koje podržavaju terorizam. U svakom slučaju, ELN je bez ikakve sumnje danas najveća pretnja za bezbednost, političku stabilnost i ekonomski razvoj Kolumbije. Njegove snage u ovom trenutku efektivno kontrolišu oko 10\% kolumbijske teritorije, odnosno njen severoistočni deo i južni deo pacifičke obale. Bez dogovora sa ELN-om, nemoguće je govoriti o normalizaciji političkih prilika u Kolumbiji, a napeti politički odnosi između zvanične Bogote i Karakasa, odnosno Havane dodatno usložnjavaju ovaj problem.

\section{OSTALE LATINOAMERIČKE GERILSKE GRUPE DANAS}

Rezultati našeg istraživanja pokazuju da i danas na prostoru Latinske Amerike postoji značajan broj aktivnih gerilskih grupa. Neke od njih i dalje 
vode oružanu borbu protiv vlada država u kojima se nalaze, a neke su napustile metode nasilne borbe i transformisale se $u$ političke partije $\mathrm{i}$ pokrete. Opasnost od ovih prvih je nesumnjiva, ali godine, pa čak i decenije nasilja koje su iza sebe ostavile ove druge ne uliva poverenje ni građanima ni vlastima sa kojima su potpisale primirje da se u nekim novim okolnostima ne bi ponovo latile oružja. U poređenju sa ove dve kategorije zajedno, manji je broj onih koje su bile objektivna pretnja po svoje države, a koje je država uspela da trajno eliminiše ili koje su se same raspale.

Tabela 1: Uništene ili raspadnute gerilske grupe u Latinskoj Americi ${ }^{5}$

\begin{tabular}{|c|c|}
\hline Naziv gerilske grupe & Država \\
\hline Brigada 2506 & Kuba \\
\hline Narodna revolucionarna vojska (ERP) & Argentina \\
\hline Takuara nacionalistički pokret (MNT) & Argentina \\
\hline Peronističke oružane snage (FAP) & Argentina \\
\hline Montoneros & Argentina \\
\hline Zarate Viljka oružane snage za oslobođenje (FAL-ZW) & Bolivija \\
\hline Nacionalna oslobodilačka vojska Bolivije (ELN) & Bolivija \\
\hline Tupak Katari gerilska vojska (EGTK) & Bolivija \\
\hline Lautaro omladinski pokret (MJL) & Čile \\
\hline Partija siromašnih (PdlP) & Meksiko \\
\hline Tupak Amaru revolucionarni pokret (MRTA) & Peru \\
\hline
\end{tabular}

${ }^{5}$ Tabela je sačinjena prema podacima dobijenim iz: Johnson 1964; Campos Gómez 1987; Brooke 1996; Rolando Torrico 1996; Bardini 2002; Pérez 2003; Arreche 2008; López et al. 2009; Muñoz 2011; Escárzaga 2012; Stavale 2012. 
Tabela 2: Latinoameričke gerilske grupe transformisane u legalizovane politicke partije i pokrete

\begin{tabular}{|c|c|}
\hline Naziv gerilske grupe & Država \\
\hline FARC-EP & Kolumbija \\
\hline Pokret 19. april (M-19) & Kolumbija \\
\hline Sandinistički front nacionalnog oslobođenja (FSLN) & Nikaragva \\
\hline Farabundo Marti front za nacionalno oslobođenje (FMLN) & El Salvador \\
\hline Tupamaros (MLN-T) & Urugvaj \\
\hline Gvatemalska nacionalna revolucionarna unija & Gvatemala \\
\hline Patriotski front Manuel Rodrigez (FPMR) & Čile \\
\hline
\end{tabular}

Tabela 3: Aktione gerilske grupe na prostoru Latinske Amerike ${ }^{7}$

\begin{tabular}{|c|c|}
\hline Naziv gerilske grupe & Država \\
\hline Vojska za nacionalno oslobođenje (ELN) & Kolumbija \\
\hline Narodna oslobodilačka vojska (EPL) & Kolumbija \\
\hline Vojska paragvajskog naroda (EPP) & Paragvaj \\
\hline Zapatistička vojska nacionalnog oslobođenja (EZLN) & Meksiko \\
\hline Narodna revolucionarna vojska (EPR) & Meksiko \\
\hline Sendero Luminoso & Peru \\
\hline Narodna vojska Borikua & Portoriko \\
\hline Bolivarijanske oslobodilačke snage & Venecuela \\
\hline
\end{tabular}

${ }^{6}$ Tabela je sačinjena prema podacima dobijenim iz: Álvarez 2011; Spooner 2011, 276; Sánchez Viesca 2015; Salgado 2018; Pupiales 2019; Duque Daza 2020; Петровић 2020.

7 Tabela je sačinjena prema podacima dobijenim iz: Azzellini 2009; ICG 2011, 16-17; InSight Crime 2018; Smink 2020; Henríquez 2020; Zavala 2020; El Periódico 2020; Muñoz Lima 2020. 
Naši rezultati istraživanja pokazuju da je tokom proteklih decenija uništeno ili se raspalo 11 relevantnih gerilskih grupa. Od toga, najviše ih je nestalo u Argentini (4) i Boliviji (3). To je sasvim razumljivo, s obzirom na to da je Argentina vodila Prljavi rat (1976-1983) protiv levičarskih gerilaca i levičara uopšte, dok je Bolivija decenijama bila pod kontrolom vojne vlasti koja se žestoko obračunavala sa levičarima. Vredna pomena je višegodišnja borba vlade Perua protiv Tupak Amaru revolucionarnog pokreta, marksističko-lenjinističke i antiimperijalističke gerilske grupe koja je bila aktivna od 1982. do 1997. godine. Nakon talačke krize u zgradi ambasade Japana u Limi 1996. godine, kada su gerilci držali kao taoce nekoliko stotina diplomata i vojnika, tadašnji predsednik Perua Alberto Fuhimori odlučio je da kroz nekoliko odlučnih i munjevitih akcija neutrališe Tupak Amaru, što je i učinjeno uz veliku podršku građana (Meza Bazán 2012, 386-398). Ostale nabrojane gerilske grupe bile su nešto manje vojne snage i političkog uticaja, izuzev Brigade 2506 koju su činile kubanske izbeglice potpomognute od strane CIA, a koje su snage Fidela Kastra uništile tokom invazije na Zaliv svinja 1961. godine.

Sa druge strane, do danas je opstalo ukupno 15 relevantnih gerilskih grupa širom Latinske Amerike, od kojih se sedam transformisalo $u$ legalizovane političke partije, dok je osam njih i dalje aktivno na terenu i u sukobu sa vladama njihovih zemalja. Transformacije ovih prvih nisu bili znaci njihove slabosti već, naprotiv, njihove snage, odnosno nemoći njihovih protivnika da ih eliminišu. Već smo pomenuli transformaciju i legalizaciju FARK-a, kao i FSLN-a i FMLN-a. Pored FARK-a, vlada Kolumbije je još 1990. godine sklopila primirje sa levičarskim i nacionalnim gerilskim Pokretom 19. april, koji je tada bio drugi po snazi u zemlji. Danas je M-19 relevantna politička partija čiji je kandidat na predsedničkim izborima u ovoj zemlji 2018. godine Gustavo Petro (Gustavo Petro), pripadnik M-19 još iz vremena gerilske borbe, bio drugoplasirani sa 4,8 miliona glasova (Duque Daza 2020, 259). Vredna pomena je i transformacija Tupamarosa, urugvajskog marksističkog gerilskog pokreta koji je sa oko 5.000 boraca u proseku vodio rat sa diktatorskim režimom u Urugvaju tokom 1960-ih i 1970-ih, da bi 1989. godine bio transformisan u političku partiju pod nazivom Pokret za narodno učešće (MPP). Danas je ova partija deo šire levičarske koalicije pod nazivom Široki front (Frente Amplio), a jedan od bivših pripadnika Tupamarosa (koji je bio zatvaran i mučen od strane diktatorskog režima) je i nadaleko poznati doskorašnji predsednik Urugvaja Hose Muhika (José Mujica) (Петровић 2020, 22). 
Nasuprot pomenutima, gerilske grupe koje su i dalje aktivne predstavljaju jednu od najznačajnijih bezbednosnih pretnji za njihove zemlje, a neke od njih (poput pomenutog ELN-a) i za region. Sem Pokreta revolucionarne levice u Čileu, koji je 2016. godine konačno pokrenuo proces legalizacije, ostali gerilci su i dalje aktivni na terenu. Pored ELN-a, vlada Kolumbije se i dalje obračunava sa pripadnicima EPL-a, takođe marksističkom levičarskom grupom. Ona deluje prevashodno u provinciji Severni Santander i procenjuje se da ima oko 140 aktivnih i naoružanih gerilaca. Iako je u poslednjih nekoliko godina izgubila čak trojicu lidera, i dalje predstavlja realnu bezbednosnu pretnju u tom regionu, ali i za Venecuelu čiju granicu neretko prelazi podstičući na pobunu tamošnje lokalno stanovništvo (InSight Crime 2018).

Slične probleme ima i Paragvaj sa EPP-om. Iako je ova gerilska grupa koja se zalaže za uspostavljanje socijalističke i antiimperijalističke države nastala tek 2008. godine, te ima tek oko 100 pripadnika, izvela je do sada nekoliko desetina operacija u kojima je ubila oko 70 policajaca, vojnika i civila. Napadi iz zaseda i otmice su njihovi najčešći metodi borbe. Tako su u jednoj zasedi vojnog konvoja 2016. godine ubili 8 vojnika, a 2020. godine su oteli bivšeg potpredsednika Paragvaja Oskara Denisa (Óscar Denis). Paragvajska javnost već godinama optužuje vlasti u Asunsionu da su nesposobne da eliminišu ovu malu, ali očigledno moćnu gerilsku grupu. Zahvaljujući intenzivnom stvaranju novih ćelija i nepristupačnosti terena na kome se inače kreću, paragvajski gerilci vešto uspevaju da budu ispod radara vojske i policije (Smink 2020).

U Meksiku od 1994. godine do danas deluje EZLN, odnosno zapatistička vojska. I ovde je reč o levičarskoj gerilskoj grupi koja ima naglašenu antiimperijalističku, antikapitalističku i antiglobalizacijsku komponentu. Deluje na prostoru južne meksičke države Čiapas i procenjuje se da broji preko 7.000 pripadnika (vojnika i civila). Većinu pripadnika grupe koja nosi naziv po čuvenom meksičkom agrarnom reformatoru Emilijanu Zapati (Emiliano Zapata) čine Maje, te ona spada u red grupa koje se bore za veća prava autohtonih naroda. Zapatisti su se prvi put pobunili januara 1994. godine nezadovljni socioekonomskim i političkim položajem Maja u Čiapasu (isprovocirani NAFTA sporazumom između Meksika i SAD), zauzevši čak grad San Kristobal de las Kasas. Meksička vojska je povratila grad, ali je pod pritiskom međunarodne javnosti došlo do potpisivanja San Andrejskog sporazuma sa gerilcima. Tako su zapatisti dobili izvesni stepen autonomije koji su iskoristili da izgrade sopstveni 
sistem opština, zadruga, ali i paralelan zdravstveni i socijalni sistem (Meneses et al. 2012). Već 27 godina traje nategnuto primirje između meksičke vlade i zapatista, gde vlada nema punu kontrolu nad bar $1 / 3$ teritorije Čiapasa. Danas nema otvorenih oružanih sukoba između zapatista i vladine vojske i policije (iako su zapatisti i dalje naoružani i imaju punktove na ulazu u njihove teritorije), ali je ELZN već godinama na udaru desničarskih paramilitaraca u Čiapasu (Orcao), koji im napadaju punktove, centrale, ali i otimaju i muče članove (Henríquez 2020). Uprkos tome, postojanje bilo kakvog paralelnog sistema i institucija na teritoriji neke zemlje samo po sebi je velika i ozbiljna opasnost za njeno funkcionisanje $u$ celini, posebno u kontekstu drugih bezbednosnih izazova sa kojima se Meksiko suočava (poput međusobnih obračuna narko-kartela, kao i obračuna sa vojskom i policijom). Pored ELZN-a, Meksiko ima probleme i sa EPR-om u saveznim državama Gerero i Oaksasa na jugu. Reč je o marksističko-lenjinističkim gerilcima koji se zalažu za stvaranje socijalističkog Meksika. Pored meksičke vlade, EPR je suprotstavljen i narko-kartelima Gereros Unidos i Golfskom kartelu, a sarađuju sa pomenutim zapatistima. Deluju od 1996. godine izvodeći atentate, bombaške napade, praveći zasede i uopšte vodeći rat niskog intenziteta. Iako su federalni agenti 2007. godine eliminisali njihova dva lidera, grupa i dalje deluje na terenu (posebno u Oaksasu), mada su procene o broju njihovih pripadnika i vojnoj snazi neprecizne. Grupa se trenutno tretira kao aktivna i u fazi konsolidacije zarad budućih napada (Zavala 2020).

U centralnom delu Perua još uvek je aktivan Sendero Luminoso, militantna komunistička gerilska grupa. Iako je osnovana još 1960-ih, ova grupa je bila najaktivnija tokom 1980-ih i početkom 1990-ih godina kada ju je vodio Abimael Guzman (Abimael Guzmán). Zalažući se za stvaranje komunističke države u Peruu po uzoru na maoistički model u Kini i kulturnu revoluciju, te snažno podupirući ideju internacionalne revolucije, Sendero Luminoso je, zajedno sa Tupak Amaru revolucionarnim pokretom, 17. maja 1980. godine započeo oružani sukob protiv vlade Perua. Taj sukob je zvanično trajao sve do 2002. godine i odneo je skoro 70.000 života. Posle građanskog rata $\mathrm{u}$ Kolumbiji, bio je to najduži oružani sukob na prostoru Latinske Amerike. Sendero Luminoso je vršio atentate, bombaške napade i otvorenu uličnu (gerilsku) borbu protiv vladinih vojnih i policijskih snaga. Do početka 1990-ih Sendero Luminoso je brojao nekoliko hiljada pripadnika. Za vreme vladavine Alberta Fuhimorija paravojne desničarske formacije su legalizovane i one su, zajedno sa vojskom i policijom, u seriji 
jakih vojnih ofanziva gotovo u potpunosti potukle gerilce (Escárzaga 2001). Od 2003. godine do danas, Sendero Luminoso je u opadanju i podeljen je na nekoliko manjih grupa koje mahom deluju u unutrašnjosti Perua. Uprkos tome, opasnost od istog je i dalje prisutna. Vlada Perua Sendero Luminoso tretira kao aktivnu terorističku organizaciju, a kao takvu su je još pre označile i vlade SAD, Kanade, Evropske unije i Japana. Tako je peruanska policija 2. decembra 2020. godine izvela opsežnu akciju hapšenja 70 osoba povezanih sa Sendero Luminosom, a koje su razvijale nove terorističke ćelije kako bi izvele napade u Limi i drugim većim peruanskim gradovima (El Comercio 2020). Samo dvadesetak dana kasnije, Sendero Luminoso je u znak odmazde u zasedi ubio jednog, a ranio tri peruanska vojnika u regionu Junin. Ono što posebno zabrinjava peruansku vladu jeste to što su se gerilci povezali sa kriminalnim klanovima koji švercuju drogu, kojima obezbeđuju zaštitu pri transportu robe, a koji ih zauzvrat finansiraju. Upravo zato je ministarka unutrašnjih poslova Perua, Nurija Esprač (Nuria Esprach), najavila još odlučniju borbu države protiv ove grupe u narednom periodu (El Periódico 2020).

Na tlu Portorika još od 1976. godine deluje Narodna vojska Borikua, nacionalistička gerilska grupa koja se zalaže za nezavisni i socijalistički uređeni Portoriko, odnosno njegovu dekolonizaciju. Stoga je glavni neprijatelj ove grupe zvanični Vašington, premda sa negodovanjem gleda i aktuelnu guvernersku vlast $u$ San Huanu. Stoga su popularni "mačeterosi" svoje napade izvodili ne samo na tlu ostrva, već i u kontinentalnoj SAD. Za njih je specifično da deluju preko svojih malih ćelija koje broje svega nekoliko ljudi, premda je na vrhuncu svoje moći brojala skoro 6.000 pripadnika. Tokom proteklih decenija izvodili su brojne akcije u kojima su napadali američke vojnike stacionirane u Portoriku, vršili pljačke državne imovine i sabotirali rad važnih strateških objekata poput aerodroma, elektrana i sl. (Ojeda Ríos 2008). Danas, međutim, petnaest godina nakon ubistva njihovog lidera Filiberta Ohede Riosa (Filiberto Ojeda Ríos), grupa ne beleži značajnije aktivnosti iako se svrstava u aktivne gerilske grupe. Broj njenih pripadnika danas nije poznat, kao ni njena opremljenost i logistika, a pretpostavka je da je grupa napustila klasični vojni metod borbe i da se fokusirala na infiltriranje svojih članova $u$ obaveštajne službe SAD (Muñoz Lima 2020).

Bolivarijanske oslobodilačke snage jedina su relevantna aktivna gerilska grupa na tlu Venecuele. Nastala je 1992. godine i, uprkos tome što se zalaže za socijalizam, bolivarijanizam i antiimperijalizam, nije obustavila svoje 
aktivnosti nakon što su čavisti došli na vlast. Štaviše, svoju najpoznatiju akciju je izvela 2003. godine kada je izvela napad na ambasadu Španije i konzulat Kolumbije u Karakasu. Smatra se, ipak, da je bila blisko povezana sa režimom Uga Čaveza i da mu je služila za zaštitu granice sa Kolumbijom u slučaju pokušaja kopnene invazije na Venecuelu dirigovane od strane zvaničnog Vašingtona. Sa druge strane, otkako je Nikolas Maduro nasledio Čaveza 2013. godine odnosi između vlade i gerilaca su se zaoštrili. Nema preciznih podataka o broju pripadnika Bolivarijanskih oslobodilačkih snaga. Pouzdano se zna da su 2005. godine brojale oko 4.000 pripadnika prevashodno koncentrisanih u saveznoj državi Apure na granici sa Kolumbijom (ICG 2011, 16-17). Međutim, baš kao i u slučaju portorikanskih mačeterosa, iako se ova gerilska grupa i dalje smatra aktivnom, teško je danas proceniti njenu snagu i opasnost koja od nje preti. Dugo godina je sarađivala sa kolumbijskim FARK-om, te bila u sukobu sa ELN-om koji i do danas traje, a što može biti dodatni izazov $\mathrm{u}$ ionako napetom odnosu između zvaničnog Karakasa i Bogote.

\section{ZAŠTO LATINOAMERIČKA GERILA IMA BUDUĆNOST?}

Gerilske grupe su deo prošlosti i sadašnjosti latinoameričkog prostora, a mnogi indikatori ukazuju na to da će neizostavno biti deo i njene budućnosti. Bez iole bezbednog okruženja teško je govoriti o političkom, ekonomskom i socijalnom razvoju u Latinskoj Americi u doglednoj perspektivi, a aktivne gerilske grupe značajno doprinose remećenju bezbednosne kulture. Nekoliko je faktora zbog kojih će Latinska Amerika i dalje morati ozbiljno da računa na gerilske pokrete na svojoj teritoriji, a to su faktori koji su i pogodovali njihovom nastanku, odnosno negativni politički i socio-ekonomski faktori koji ni do danas nisu iskorenjeni.

\section{Nedostatak razvijene demokratske kulture}

Latinoameričke zemlje još od njihovog osamostaljenja početkom XIX veka karakteriše politička nestabilnost. Sve one su prošle kroz neki oblik građanskog rata i kroz diktatorske ili vojne režime. Visok stepen demokratske političke kulture nikada nije izgrađen. Borba za vlast često se svodila na uzak krug ljudi čiji je cilj bio da državu pretvore u privatno vlasništvo i da sve njene sisteme stave u svoju i službu uskog partijskog 
kruga. Većina zemalja ima nestabilne političke sisteme i polarizovane partijske sisteme, gde je teško zamisliti saradnju političke levice i desnice zarad odbrane nekih vitalnih nacionalnih interesa. Nasilni politički protesti, pučevi i prevrati i danas su prisutna pojava širom Latinske Amerike. Dovoljno je samo videti nedavna dešavanja tokom svrgavanja Eva Moralesa sa vlasti u Boliviji ili sukobe tokom protesta u Venecueli, Čileu i Kolumbiji. Kada tome dodamo istorijski prisutan politički revanšizam, jasno je da u političkom smislu postoje preduslovi za upotrebu nasilnih metoda zarad osvajanja vlasti, gde je gerilska borba jedna od ustaljenih metoda.

\section{Američki imperijalizam i neokolonijalizam}

SAD već dva veka vode imperijalističku i neokolonijalnu politiku u Latinskoj Americi i teško je za očekivati da će se ona u dogledno vreme promeniti. Od Monroove doktrine (1823) prema kojoj „Amerika pripada Amerikancima", preko de facto kolonijalne uprave na Kubi i Portoriku, pa sve do niza tajnih operacija američkih tajnih službi u svrgavanju njima nepodobnih režima i likvidaciji levičarskih grupa pod kodnim imenom „Kondor", zvanični Vašington je imao agresivan pristup prema ovom prostoru, što izaziva revolt tamošnjeg stanovništva. Sve pomenute gerilske grupe, uključujući i one koje su i danas aktivne, imaju izrazite antiameričke, antiimperijalističke i antineokolonijalne stavove. Pored negativnog odnosa prema političkim i vojnim institucijama SAD, levičarski nastrojeno stanovništvo Latinske Amerike protivi se delovanju američkih multinacionalnih korporacija, koje ne samo da vide kao deo vašingtonske političke i obaveštajne agenture, već i kao besomučne eksploatatore latinoameričkih prirodnih resursa i njene radne snage. S obzirom na to da su SAD, pa čak i njene multinacionalne kompanije u Latinskoj Americi, neretko upotrebljavale različite oblike političkog nasilja zarad ostvarivanja svojih ciljeva, jasno je da je to jedan od važnih uzroka postojanja gerilskih levičarskih grupa na tom prostoru i gerile kao metoda borbe.

\section{Socijalna nejednakost i visoka stopa siromaštva}

Latinska Amerika je region sa najizraženijom socijalnom nejednakošću na svetu. Najveće razlike u visini prihoda tokom 2019. godine, prema izveštaju Programa za razvoj Ujedinjenih nacija, zabeležene su upravo u ovom regionu (dakle, veće nego u npr. subsaharskoj Africi). Tako 10\% 
najbogatijih u Latinskoj Americi dobija 37\% od ukupnih prihoda, dok 40\% siromašnih dobija $13 \%$ od ukupnih prihoda. U posebno osetljive grupe spada urođeničko stanovništvo i stanovništvo afričkog porekla, s obzirom na to da su u najvećem riziku da budu siromašni i ostanu bez formalnog obrazovanja. Tako je stopa siromaštva urođeničkog stanovništva 2018. iznosila čak $49 \%$, duplo više u odnosu na ostale etničke grupe. U Meksiku, gde urođenici čine $15 \%$ stanovništva, $3 / 4$ ih živi u uslovima siromaštva, a čak $43 \%$ onih kojima je neki od lokalnih jezika maternji nisu završili ni osnovnu školu (Lissardy 2020). U uslovima u kojima je veliki deo stanovništva neobrazovan i živi u (ekstremnom) siromaštvu za očekivati je da gerilske grupe svojim ideološkim delovanjem, programima socijalne pomoći, ali i pretnjama i prinudom mogu ostvariti značajan uticaj (regrutacija boraca, skrivanje, uspostavljanje paralelnih sistema vlasti itd.). U uslovima opšte socijalne i ekonomske krize u kojima se latinoamerički region nalazi, te usled nerazvijene demokratske političke kulture, nasilje vrlo lako postaje jedini kanal za iskazivanje ogromnog nezadovoljstva.

\section{Endemska korupcija, kriminal i narkokriminal}

Zemlje Latinske Amerike spadaju među najkorumpiranije prema podacima za 2020. godinu. Ukupno gledano, na skali od 0 do 100, Latinska Amerika kao region beleži korupciju od 67,65. Sem Urugvaja (26), Čilea (30) i Kostarike (42), sve ostale zemlje beleže vrednosti korupcije preko 50, s tim što je ona veoma izražena u Venecueli (97), na Haitiju (89), u Nikaragvi (86), Hondurasu (80) i Gvatemali (80) (CESLA 2020). Čak 33\% kriminalnih slučajeva na svetskom nivou otpada na Latinsku Ameriku, iako u njoj živi tek $8 \%$ ukupne svetske populacije, što je čini najnasilnijim regionom na svetu. Od 2000. do 2015. godine stopa ubistava u Latinskoj Americi porasla je za $12 \%$. Primera radi, 2016. godine 17 od 20 zemalja i 47 od 50 gradova sa najviše ubistava bilo je upravo iz Latinske Amerike. Ovome je u značajnoj meri doprinela viska urbanizacija stanovništva $(80 \%$ Latinoamerikanaca živi u gradovima) i stvaranje sve većih siromašnih i nebezbednih predgrađa, poput favela u Brazilu (Medellín 2020). Trgovina drogom je posebno bolna tačka Latinske Amerike. Prema izveštaju UN-a za 2018. godinu, čak $85 \%$ zaplenjene količine droge otpada na ovaj region. Tako se u prvih pet zemalja po količini zaplenjene droge nalaze četiri latinoameričke - Kolumbija (1. mesto u svetu), Meksiko, Peru i Brazil (Telesur 2020). Nekada su kolumbijski narko-karteli poput Medeljina i Kalija bili jedni od 
najmoćnijih na svetu, a danas je Meksiko država koja je dom narko-kartela koji važe za najopasnije i najuticajnije u regionu - Sinaloa kartel, Halisko nova generacija, Zetas, Zalivski kartel i dr. Meksiko još od 2006. godine vodi rat protiv narko-kartela, u kome je svih ovih godina učešće uzelo nekoliko stotina hiljada ljudi, a na desetine hiljada su izgubile živote (Rosen and Zepeda Martínez 2015). Gerilske grupe često sarađuju sa narkokartelima jer imaju zajedničke neprijatelje i uslovi poput ovih u Meksiku i te kako pogoduju njihovom razvoju (sami meksički narko-karteli imaju mnoge osobine gerilskih grupa, premda im nedostaje ideologija, odnosno politička dimenzija delovanja).

\section{ZAKLJUČAK}

Gerilske grupe danas predstavljaju objektivnu bezbednosnu pretnju za prostor Latinske Amerike. Iako je značajan broj u proteklih nekoliko decenija rasformiran ili uništen, te iako se nekoliko najznačajnijih gerilskih grupa transformisalo $u$ političke partije koje su legalizovane, još uvek postoji značajan broj onih koje su aktivne i koje u većoj ili manjoj meri ugrožavaju bezbednost date zemlje, a neretko i onih okolnih. Kolumbija, Paragvaj, Meksiko, Peru, Portoriko i Venecuela zemlje su u kojima, pored niza drugih problema i izazova, bezbednost građana ugrožavaju i gerilci. Posebno je simptomatičan primer Kolumbije, zemlje koja je nekoliko decenija vodila građanski rat sa FARK-om, ali koja i posle potpisivanja primirja sa istim vodi borbu sa drugim gerilskim grupama, od kojih je ELN verovatno najmoćnija ne samo u toj državi, već i u celom regionu. Paragvaj ima sve više problema sa EPP-om koji preti da postane glavni bezbednosni izazov za zemlju koja ima višedecenijsko iskustvo surovog obračunavanja diktature sa levičarskim organizacijama. Isti je slučaj sa Peruom koji, uprkos tome što je početkom 2000-ih i zvanično dobio rat protiv pobunjenih komunističkih gerilaca, i dalje ne uspeva da u potpunosti neutrališe Sendero Luminoso. Štaviše, već izneti podaci ukazuju na to da se ova gerilska grupa polako, ali sigurno konsoliduje i sprema za nove napade. Glavna pretnja za bezbednost građana Meksika su narko-karteli, ali izazov za vladu u Meksiko Sitiju predstavlja i postojanje zapatističkih gerilaca koji su na značajnom delu teritorije savezne države Čiapas izgradili paralelne političke i ekonomske institucije, uz to vojno pokrivajući prostor za koji se smatra da je izvan kontrole vlade. Gerilske grupe u Venecueli i Portoriku 
predstavljaju daleko manju pretnju po bezbednost istih u odnosu na pomenute gerilske grupe, ali ih svakako treba uzeti u obzir, posebno kada je reč o Venecueli, gde unutrašnja politička i ekonomska nestabilnost, kao i napeti odnosi sa SAD i Kolumbijom mogu eskalirati u otvoreni vojni sukob. Zaključno, treba istaći da postoji čitav niz nepovoljnih faktora koji daju osnov za pretpostavku da će Latinska Amerika i ubuduće biti plodno tlo za delovanje gerilskih grupa. Tu pre svega mislimo na nedostatak razvijene demokratske kulture, američke imperijalističke i neokolonijalne interese na tom prostoru, socijalnu nejednakost i visoku stopu siromaštva, te endemsku korupciju, kriminal i narko-kriminal.

\section{BIBLIOGRAFIJA}

Álvarez, Alberto Martín. 2011. “De guerrilla a partido político: El Frente Farabundo Martí para la Liberación Nacional". Historia y Política 25 (1): 207-233.

Amorin, José. 2005. Montoneros: la buena historia. Buenos Aires: Catálogos.

Arenas Reyes, Jaime. 1971. La guerrilla por dentro: análisis del ELN colombiano. Bogotá: Tercer Mundo.

Arias Gómez, Jorge. 2012. "Farabundo Martí biografía (1893-1932)". Cuaderno de El Socialista Centroamericano 14 (1): 1-79.

Arreche, Mariano. 2008. “A 32 años de la caída en combate del comandante

Mario Roberto Santucho y de la dirección histórica del PRT-ERP",

CEDEMA, July 13. http:/ / www.cedema.org/ver.php?id=2713

Azzellini, Dario. 2009. "Ejército de Liberación Nacional, Colombia". In: International Encyclopedia of Revolution and Protest, edited by Immanuel Ness, 1081-1084. Hoboken: Blackwell Publishing.

Bardini, Roberto. 2002. Tacuara, la pólvora y la sangre. México: editorial Océano.

Betancourt, Ingrid. 2010. No hay silencio que no termine. Ciudad de México: Aguilar.

Brooke, James. 1996. "The Rebels and the Cause: 12 Years of Peru's Turmoil", The New York Times, December 19. https:/ / www.nytimes. com/1996/12/19/world/the-rebels-and-the-cause-12-years-of-peru-sturmoil.html?auth=login-facebook 
Campos Gómez, Eleazar. 1987. Lucio Cabañas y el Partido de los Pobres: una experiencia guerrillera en México. Ciudad de México: Nuestra América.

Castro, Pedro. 2007. “El caudillismo en América Latina, ayer y hoy". Política y Cultura 27 (1): 9-29.

[CESLA] Círculo de Estudios Latinoamericanos. 2020. Indicador de corrupción para América Latina. https://www.cesla.com/pdfs/ Informe-de-corrupcion-en-Latinoamerica.pdf

Defensoría del Pueblo. 2015. "Cómo fueron los 64 atentados perpetrados por las FARC en los últimos dos meses". Accessed 25 January 2021. https://www.defensoria.gov.co/es/nube/enlosmedios/3878/Cómofueron-los-64-atentados-perpetrados-por-las-FARC-en-los-últimos-dosmeses.htm

Demarest, Geoff. 2020. “The National Liberation Amry (ELN), Early 2020”. Military Review 100 (4): 86-98.

Duque Daza, Javier. 2020. "Las elecciones presidenciales de Colombia en 2018: candidatos, autocandidatos y seudocandidatos". Revista Colombiana de Ciencias Sociales 11 (1): 234-266.

Echandía Castilla, Camilo. 2013. Auge y declive del Ejército de Liberación Nacional (ELN). Análisis de la evolución militar y territorial de cara a la negociación. Bogotá: Fundación Ideas para la paz.

El Comercio. 2020. "Policía capturó a más de 70 personas que estarían vinculadas a Sendero Luminoso y Movadef esta madrugada". December 2. https://elcomercio.pe/lima/policiales/policia-captura-a70-personas-vinculadas-a-sendero-luminoso-y-movadef-estamadrugada-nndc-noticia/

El Periódico. 2020. "'No va a quedar aquí, dice la ministra de Perú tras el ataque a las fuerzas armadas". December 23. https://www.el periodico.com/es/internacional/20201223/quedar-dice-ministra-peruataque- 11418360

Escárzaga, Fabiola. 2001. "Auge y caída de Sendero Luminoso". Bajo el Volcán 3 (2): 75-97.

Escárzaga, Fabiola. 2012. “El Ejército Guerrillero Tupak Katari (EGTK), la insurgencia aymara en Bolivia". Pacarina del Sur, March 11. http:/ / www.pacarinadelsur.com/home/ oleajes/441-el-ejercitoguerrillero-tupak-katari-egtk-la-insurgencia-aymara-en-bolivia? 
Grossman, Richard. 2008. "The nation is our mother: Augusto Sandino and the construction of a peasant nationalism in Nicaragua, 1927-1934". Journal of Peasant Studies 35 (1): 80-99.

Henríquez, Elio. 2020. "Denuncian ataques armados de Orcao a pueblos zapatistas", La Jornada, November 14. https:/ / www.jornada.com.mx/ ultimas/estados/2020/11/14/denuncian-ataques-armados-de-orcaoa-pueblos-zapatistas-7627.html

Hobsbawm, Eric. 1970. "Guerrillas in Latin America". In: The Socialist Register, edited by Ralph Miliband and John Saville, 51-61. Dublin: Merlin Press.

[ICG] International Crisis Group. 2011. Violence and Politics in Venezuela. Latin America Report No. 38. https://d2071andvip0wj.cloudfront. net/38-violence-and-politics-in-venezuela.pdf

[ICG] International Crisis Group. 2019. Gold and Grief in Venezuela's Violent South. Latin America Report No. 73. https:/ / d2071andvip0wj. cloudfront.net/073-gold-and-grief.pdf

InSight Crime. 2018. "EPL". March 14. https://www.insightcrime.org/ colombia-organized-crime-news/epl/

Jenkins, Brian M. and Janera A. Johnson. 1976. “International Terrorism: A Chronology (1974 Supplement)”. ARPA Order 189 (1): 1-23.

Johnson, Haynes. 1964. The Bay of Pigs: The Leaders' Story of Brigade 2506. New York: W.W. Norton \& Co Inc.

Joxe, Alain. 1997. "Siete características de las guerrillas norteamericanas". Chiapas 5 (1): 41-46.

Krstić, Marko. 2015. „Motivi terorističkog delovanja“. Specijalna edukacija $i$ rehabilitacija 14 (4): 519-524.

Larson, Judith. 1977. “La guerrilla en América Latina ¿terrorismo o guerra popular?". Revista de Sociología 7 (1): 91-112.

Lewis, Paul H. 2002. Guerrillas and generals: the "Dirty War" in Argentina. Westport: Praeger.

Lissardy, Gerardo. 2020. "Por qué América Latina es "la región más desigual del planeta", BBC News Mundo, February 6. https://www.bbc. com/mundo/noticias-america-latina-51390621

López, A., J. Herrera and P. Carrera. 2009. “Muere Guillermo Ossandón, fundador del Lautaro y líder subversivo más buscado en los 90" , La 
Tercera, July 26. https://web.archive.org/web/20160819043435/ http://www.latercera.com/contenido/654_161165_9.shtml

Medellín, Paola. 2020. "Criminalidad y violencia ¿Una epidemia en América Latina?", Universidad Nacional de Colombia, March 6. http://ieu.unal.edu.co/medios/noticias-del-ieu/item/criminalidady-violencia-una-epidemia-en-america-latina

Meneses, Aldo, Alain Demanet, Constanza Baeza and Javier Castillo. 2012. "El movimiento zapatista: impacto político de un discurso en construcción". Revista Enfoques 16 (10): 151-174.

Meza Bazán, Mario Miguel. 2012. El Movimiento Revolucionario Túpac Amaru (MRTA) y las fuentes de la revolución en América Latina. Doctoral dissertation. Centro de Estudios Historicos, El Colegio de México.

Milašinović, Radomir and Nenad Putnik. 2007. „Gerila kao specifični vid društvenog konflikta". In: Guerrillas in the Balkans, edited by Momčilo Pavlović, Tetsuya Sahara and Predrag J. Marković, 327-338. Belgrade and Tokyo: University Meiji - Institute for Disarmament and Peace Studies, Institute for Contemporary History and Faculty of Security Studies.

Muñoz, Carmen. 2011. "Las víctimas del terror montonero no cuentan en Argentina", $A B C$, December 12. https://www.abc.es/internacional/ abci-victoria-villarruel-entrevista-201112280000_noticia.html?ref= https:\%2F\%2Fen.wikipedia.org\%2F

Muñoz Lima, Rosa. 2020. “Qué guerrillas siguen activas en América Latina?", Deutsche Welle, September 7. https:/ / www.dw.com/es/quéguerrillas-siguen-activas-en-américa-latina/a-54846709

Nubia Bello, Martha. 2013. ¡BASTA YA! Colombia: Memorias de guerra y dignidad. Bogotá: Imprenta Nacional.

Offstein, Norman. 2003. "An Historical Review and Analysis of Colombian Guerrilla Movements: FARC, ELN and EPL”. Desarrollo y Sociedad 52 (1): 99-142.

Ojeda Ríos, Filiberto. 2008. Escritos macheteros (Selección de textos). Caracas: Fundación Editorial El perro y la rana.

Pérez, Cristián. 2003. "El ejército del Che y los chilenos que continuaron su lucha". Estudios Públicos 89: 225-256.

Петровић, Рајко. 2020. Политичке идеологије у Латинској Америции. Београд: Поредак, Институт за европске студије и Друштво хиспаниста. 
Pupiales, Juan. 2019. “Estos son los excombatientes de las FARC que serán alcaldes en Colombia“, France 24, October 28. https://www.france 24.com/es/20191028-excombatientes-farc-alcaldias-colombia-paz

Rolando Torrico, Erick. 1996. "Bolivia: izquierdas en transición”. Nueva Sociedad 141 (1): 156-165.

Romero, César. 2018. "262.197 muertos dejó el conflicto armado", Centro Nacional de Memoria Histórica, August 2. https://centrodememoria historica.gov.co/262-197-muertos-dejo-el-conflicto-armado/

Rosen, Jonathan Daniel and Roberto Zepeda Martínez. 2015. “La guerra contra el narcotráfico en México: una guerra perdida". Rev. Reflexiones 94 (1): 153-168.

Salgado, María Mercedes. 2018. "Activismo de alto riesgo: el Frente Sandinista de Liberación Nacional (FSLN) ¡Patria libre o morir!”. Anuario de Estudios Centroamericanos 44 (1): 367-398.

Sánchez Viesca, Ángel Fernando. 2015. La construcción del sujeto revolucionario: 30 años de la Unidad Revolucionaria Nacional Guatemalteca - URNG - en Guatemala (1982-2012). Master thesis. Escuela de Ciencia Política, Universidad de San Carlos de Guatemala.

Smink, Veronica. 2020. “Por qué Paraguay no ha logrado derrotar al EPP, el grupo guerrillero que mantiene secuestrado a un exvicepresidente", BBC News, September 17. https://www.bbc.com/mundo/noticiasamerica-latina-54182505

Spooner, Mary Helen. 2011. The General's Slow Retreat: Chile After Pinochet. Oakland: University of California Press.

Stavale, Mariela. 2012. Las Fuerzas Armadas Peronistas y su experiencia alternativa (1964-1979). Trabajo final de grado. Facultad de Humanidades y Ciencias de la Educación, Universidad Nacional de La Plata.

Telesur. 2020. "Narcotráfico según la ONU: Los patrones en América Latina". July 2. https://www.telesurtv.net/news/america-latinadrogas-venezuela-colombia-20200701-0021.html

Zavala, Juan Carlos. 2020. "EPR, la guerrilla con 26 años en resistencia por la que está prófugo un exprocurador oaxaqueño", El Universal, August 3. https:// oaxaca.eluniversal.com.mx/sociedad/03-09-2020/epr-laguerrilla-con-26-anos-en-resistencia-por-la-que-esta-profugo-un 


\section{GUERRILLA GROUPS AS A PERMANENT SECURITY THREAT FOR LATIN AMERICAN COUNTRIES}

Abstract: The activities of guerrilla groups in Latin America, as well as the security challenges they pose, are the focus of our research. We start from the assumption that for 70 years now, various national and mostly leftwing paramilitary guerrilla groups have been the biggest security threat both to the countries there individually and to the Latin American region as a whole. The results of the research indicate that some guerrilla groups, after years and even decades of struggle, rejected armed struggle as a method of gaining power and transformed into legalized political movements or parties, but also that some of them continue to act and endanger the security of individual states and the whole region, and then political stability and economic development in them. The conclusion is that social inequality, high poverty rate, endemic corruption and lack of developed democratic culture are preconditions that affect the survival of guerrilla warfare in order to achieve political goals in Latin America, but also guarantee that this security challenge will continue to exist on its territory. In the theoretical-conceptual sense, we will explain the concept and significance of guerrilla warfare, the Latin American model of dictatorship (caudilism) and the Latin American left. In the methodological sense, we will use the case study method, the comparative method and the analysis method.

Keywords: Latin America, guerrillas, Montoneros, Revolutionary Armed Forces of Colombia, National Liberation Army, Latin American left, caudilism. 